$7^{\text {th }}$ and $8^{\text {th }}$ December $2015 \mid$ Colombo, Sri Lanka

\title{
Analysis of Public Satisfaction on Services Quality of Urban Local Authorities in Sri Lanka
}

\author{
H.M.L.P. Karunarathne (lakshikarunarathne@sjp.ac.lk) \\ Lecturer (Probationary), University of Sri Jayewardenepura \\ W.H.T.Gunawardhana(terans@sjp.ac.lk) \\ Lecturer (Probationary), University of Sri Jayewardenepura \\ J. Edirisinghe( jediri@sjp.ac.lk) \\ Senior Lecturer, University of Sri Jayewardenepura
}

\begin{abstract}
Local Authorities are in the lowest level administration structure in Sri Lanka. As enormous amount of literature suggest, service quality and beneficiaries satisfaction are very important concepts that local authorities must understand in order to remain efficient and effective. Accordingly, SERVQUAL is one of best models used in measuring level of service quality of local authorities. This paper aims to measure the satisfaction level of beneficiaries' in selected Urban Local Authorities in Colombo district using SERVQUAL model and describe how beneficiaries perceive service quality and whether they are satisfied with services offered by local authorities. Colombo Municipal Council (CMC), Dehivala Mount Lavinia MC, Mahagaragama UC and Boralesgamuwa UC limits were selected as sampling framework. Unit of analysis is beneficiaries and 50 beneficiaries were interviewed in each authority using seven point Likert scaled, self-administered questionnaire. Data was analyzed as per the SERVQUAL model with help of SPSS 20.0 package. Considering all aspects by which public are satisfied related to the services provided by the local authorities in selected sample, Maharagama UC is providing expected services as it is; with a small gap -0.02. Also CMC's gap -0.11 indicates a better sign of their services without having a large deviation from the expected level. However, Boralesgamuwa UC is the most inefficient services providing local authority which scores a 3.00 gap. As per the gap shows, Dehiwal Mt. Levenia is also slightly weak service providing local authority. However, further research on this area is required to verify the findings and find out the reasons/causes to the dissatisfaction (gap) of the people who look for services from Local Authorities in Sri Lanka.
\end{abstract}

\footnotetext{
Faculty of Management Studies and Commerce

University of Sri Jayewardenepura

Gangodawilla, Nugegoda

E-Mail: icbm@sjp.ac.lk

WEB: www.icbmusjp.org, mgt.sjp.ac.lk
} 
$7^{\text {th }}$ and $8^{\text {th }}$ December $2015 \mid$ Colombo, Sri Lanka

Keywords: Service quality, Satisfaction, SERVQUAL model, Urban local authorities

\section{JEL Classification: M39}

\section{Introduction}

Rodríguez, Burguete, Vaughan \& Edwards, (2009), as cited in (Mokhlis, Aleesa, \& Mamat, 2011) expressed quality as a pivotal factor for the transformation of municipal services and a critical driving force for better satisfaction of citizens. Therefore, delivery system with efficiency and effectiveness becomes the main focus of the government of many countries due to insistence and hopes from society for local authorities giving their services up to the quality standard as expected by the tax payers (Mokhlis et al., 2011). However, providing high quality and cost-effective public services is not an easy task. It involves creating organizations with the right approaches, establishing clear ways of delivering services and putting the right people in right place to respond to the needs of citizens. It also requires a combination of good policy development, successful implementation, a good understanding of citizens' needs and expectations, appropriate resources and technology, a responsive organizational culture and well trained staff (Mokhlis et al., 2011).

In literature of service marketing, generally, the quality of the service defined as the overall assessment of a service by the customers, (Daniel \& Berinyuy, 2010) or the extent to which a service meets customer's needs or expectations, (Daniel \& Berinyuy, 2010). Further, (Parasuraman, Zeithaml, \& Berry, 1985); (Daniel \& Berinyuy, 2010) define service quality as “The discrepancy between consumers' perceptions of services offered by a particular firm and their expectations about firms offering such services". If the expectation of consumer is below what is perceived by consumer, consumer will judge the quality as low and if what is perceived by consumer meets or exceeds expectation then consumer sees the quality as high which was expected. The identified critical component of quality service are; consumer's expectation which is seen as what they feel service provider should offer and this is influenced by his/her past experience, personal needs, word-of-mouth and service provider's communications, (Parasuraman et al., 1985); (Daniel \& Berinyuy, 2010). And also, consumers' perception of performance is considered as what consumer experiences, (Parasuraman et al., 1985); (Daniel \& Berinyuy, 2010). 
$7^{\text {th }}$ and $8^{\text {th }}$ December $2015 \mid$ Colombo, Sri Lanka

Generally speaking, it is interesting to study expectations and experiences of consumers in many different types of views. It is important to study these concepts in the context of urban local authorities as well. Because, as cited in (Mokhlis et al., 2011), understanding exactly what the citizen expects is the most important step in defining and delivering quality service. Further, gaining citizen feedback also provides valuable insight into how well the municipal authority meets their customers' needs. This information can be used in quality improvement programs to help municipal councilors to recognize opportunities to improve services and for creation of a positive perception among citizen. Quantitative assessment of service quality can also identify gaps between citizens' perceptions of municipal services and that of councilors. Moreover, service quality assessments can be used as a strategic tool for marketing municipal services (Mokhlis et al., 2011).

Service quality and beneficiaries satisfaction are significant concepts that local authorities must understand in order to remain efficient and effective. It is very important for local authorities to understand how to measure these constructs from the beneficiaries' perspective in order to better understand their needs and hence satisfy them. This will also enable us to identify strengths and weaknesses in service quality of urban local authorities. Summarily, our goal is to understand both the expectations and perceptions of customers and also measure them from their perspective in order to identify gaps in delivering service quality in order to ensure customer satisfaction.

\section{Objectives of the Study}

\section{General Objective:}

The purpose of this study is to analyze the satisfaction of beneficiaries on services of urban Local Authorities in Sri Lanka

\section{Specific Objectives:}

1. To identify the determinants of service quality of Urban Local Authorities

2. To analyze the satisfaction level of public on service quality of Urban Local Authorities

\section{Significant of the Study}

Service organizations have begun focusing on the customer perceptions of service quality because it helps in developing strategies that lead to satisfaction of the customer. This study aims at determination of the overall service quality perceived by beneficiaries in Urban Local 
$7^{\text {th }}$ and $8^{\text {th }}$ December $2015 \mid$ Colombo, Sri Lanka

Authorities and identify those dimensions that bring satisfaction to beneficiaries. This study will enable urban local authorities to identify the most effective ways of closing service quality gaps and choose which gaps to be focused on. This will be achieved by measuring the beneficiaries' expectations and performance on the various dimensions hence evaluating the gap scores obtained between the beneficiaries' expectations and perception of service experienced. This will also enable to identify strengths and weaknesses in service quality of Urban Local Authorities.

\section{Literature Review}

\subsection{Service Concept}

According to Johns (1998), as cited in (Daniel \& Berinyuy, 2010) points out that the word 'service' has many meanings which lead to some confusion in the way the concept is defined in management literature, service is meant an industry, a performance, an output or offering or a process. Further researcher argues that services are mostly described as 'intangible' and their output viewed as an activity rather than a tangible object which is not clear because some of service outputs indicate some important tangible components like physical aspects of facilities, equipment and personnel. Edvardsson, (1998), as cited in (Daniel \& Berinyuy, 2010) explain that the service concept should be approached from the customer's perspective because it is the customer's total perception of the outcome which is the 'service' and customer outcome was created in process of meaning service is generated through that process. He points out the participation of the customer in the service process since he/she is a co-producer of service and the customer's outcome evaluated in terms of value added and quality meaning the customer will prefer service offered to be of high value and quality.

\subsection{Service Quality}

Quality of service is expected a great deal of attention from both of practitioners and academicians (Negi, 2009) and literature of services marketing, quality of service is defined as the overall assessment by the customer on the service which is provided. (Daniel \& Berinyuy, 2010). (Daniel \& Berinyuy, 2010) points out that, by defining the quality of service, the organizations will create ability to deliver services with higher quality level presumably resulting in increased customer satisfaction (Parasuraman et al., 1985); (Ladhari, 2008). 
In this study, quality of service is defined as the "difference between customer's expectation for service performance prior to the service encounter and their perception of the service received". Customer's expectation serves as a foundation for evaluating service quality because, quality is high when performance exceeds expectation and quality is low when performance does not meet their expectation (Daniel \& Berinyuy, 2010). The customer's total perception of a service is based on his/her perception of the outcome and the process; the outcome is either value added or quality and the process is the role undertaken by the customer (Daniel \& Berinyuy, 2010). (Parasuraman, Zeithaml, \& Berry, 1988) define perceived quality as a form of attitude, related but not equal to satisfaction, and results from a consumption of expectations with perceptions of performance.

(Parasuraman et al., 1985) have proposed that customer's perception of service quality is based on the comparison of their expectations (what they feel service providers should offer) with their perceptions of the performance of the service provider. (Parasuraman et al., 1988) point out that expectation is viewed differently in both satisfaction literature and service quality literature. In satisfaction literature, expectations are considered as 'predictions' by customers about what is likely to happen during a particular transaction while in service quality literature, they are viewed as 'desires or wants of consumers', that is, what they feels a service provider 'should' offer rather than 'would' offer.

(Parasuraman et al., 1985) identified 10 determinants used in evaluating service quality; reliability, access, competence, communication, courtesy, credibility, security, responsiveness, tangibles and understanding the customer. Most of these service quality determinants require the consumer to have some of experiences for the evaluation of their level of service quality ranging from ideal quality to completely unacceptable quality. Further service quality is linked with the satisfaction by emphasizing that, expected level of service is greater than perceived level of service, perceived quality level is less than satisfactory and will tend towards totally unacceptable quality level; when expected service level is equaled perceived level of service, perceived quality level is satisfactory; when expected service level is less than perceived service level, perceived quality is more than satisfactory and will tend towards ideal quality (Parasuraman et al., 1985).

Accordingly, (Parasuraman et al., 1985) suggested that when perceived service quality is high, then it will lead to increase in customer satisfaction. Further argue that service quality leads to customer satisfaction and this is in line with (Saravana \& Rao, 2007); (Lee et al., 
$7^{\text {th }}$ and $8^{\text {th }}$ December $2015 \mid$ Colombo, Sri Lanka

2000); (Daniel \& Berinyuy, 2010) who acknowledge that customer satisfaction is based upon the level of service quality provided by the service provider.

\subsection{SERVQUAL Model}

Lovelock and Wirtz (2007), as cited in (Kabir \& Carlsson, 2010) discusse that to measure customer satisfaction with various aspects of service quality, Valarie Zeithaml, et al., developed a service research instrument called "SERVQUAL" is highly suitable. This model is based on the premises by which customers can evaluate a firm's service quality through comparing their perception of its service and with their own expectations. SERVQUAL is seen as a generic measurement tool that can be applied across a broad spectrum of service industries.

(Parasuraman et al., 1985) provided a list of ten determinants of service quality as a result of their discussion with service providers and customers: access, communication, credibility, competence, reliability, security, responsiveness, understanding, courtesy and tangibles. In a later article that year (Johnston, 1995) they added that: although the relative importance of the categories would vary from one service industry to the next, determinants of service quality in most (if not all) consumer service industries are included in this list. In the next phase of their research, (Johnston, 1995) found a high degree of correlation between, on the one hand, communication, competence, courtesy, credibility and security, and, on the other, between access and understanding; and so they created the two broad dimensions of assurance and empathy, that is, five consolidated dimensions. They then used the five dimensions - tangibles, reliability, responsiveness, assurance and empathy - as the basis for their service quality measurement instrument, SERVQUAL [(Parasuraman et al., 1988); (Yi, 1990). They reported further that, regardless of the service being studied, reliability was the most important dimension, followed by responsiveness, assurance and empathy. The intangibles were of least concern to service customers.

(Parasuraman et al., 1988) argues that SERVQUAL must be reliably assessed and measured in order to improve services quality. (Parasuraman et al., 1988) further indicated that "In service literature the gap model is the most reliable and has the most valuable contributions". The model emphasis four key internal gaps relating to managerial perception of service quality, and tasks which is connected with service delivery to customers. Both the actual version of SERVQUAL (Parasuraman et al., 1988) and its modified version 
(Parasuraman et al.,1991) developed five dimensions of service quality like tangibles, reliability, responsiveness, assurance, and empathy

Accordingly, the original SERVQUAL instrument identified five constructs of service quality such as;

1. Tangibles: this construct was focused on physical environment. It considers customer assessments of the facilities, appearance and equipment, those providing the services.

2. Reliability: This construct deals with perceptions of customer that the provider of service is giving the promised service in a reliable and dependable manner, and is doing on time.

3. Responsiveness: This construct deals with perceptions of customer about the willingness of the service provider to help the customers and not shrug off their requests for assistance.

4. Assurance: This construct deals with customer perceptions that the service provider's behavior instills confidence in them through the provider's courtesy and ability.

5. Empathy: This construct deals with customer perceptions that the service provider is giving them individualized attention and has their best interests at heart (Benlian, Koufaris, \& Hess, 2012); (Hi and Li, 2011).

From the beginning, SERVQUAL has been widely used in replication studies in a variety of industrial, commercial and not-for-profit settings, to assess quality of service provision in terms of what customers expect and what they actually receive. As an example, the scale has been applied to measure service quality in hotels, healthcare, public transports, tourism, banking, library, police service, courier service, municipal services and higher education (Mokhlis et al., 2011).

Accordingly, Parasuraman's SERVQUAL Model with five dimensions will be used in this study for measuring service quality in Urban Local Authorities in Sri Lanka. Following shows the conceptual framework of this study, 


\section{Conceptual Framework}

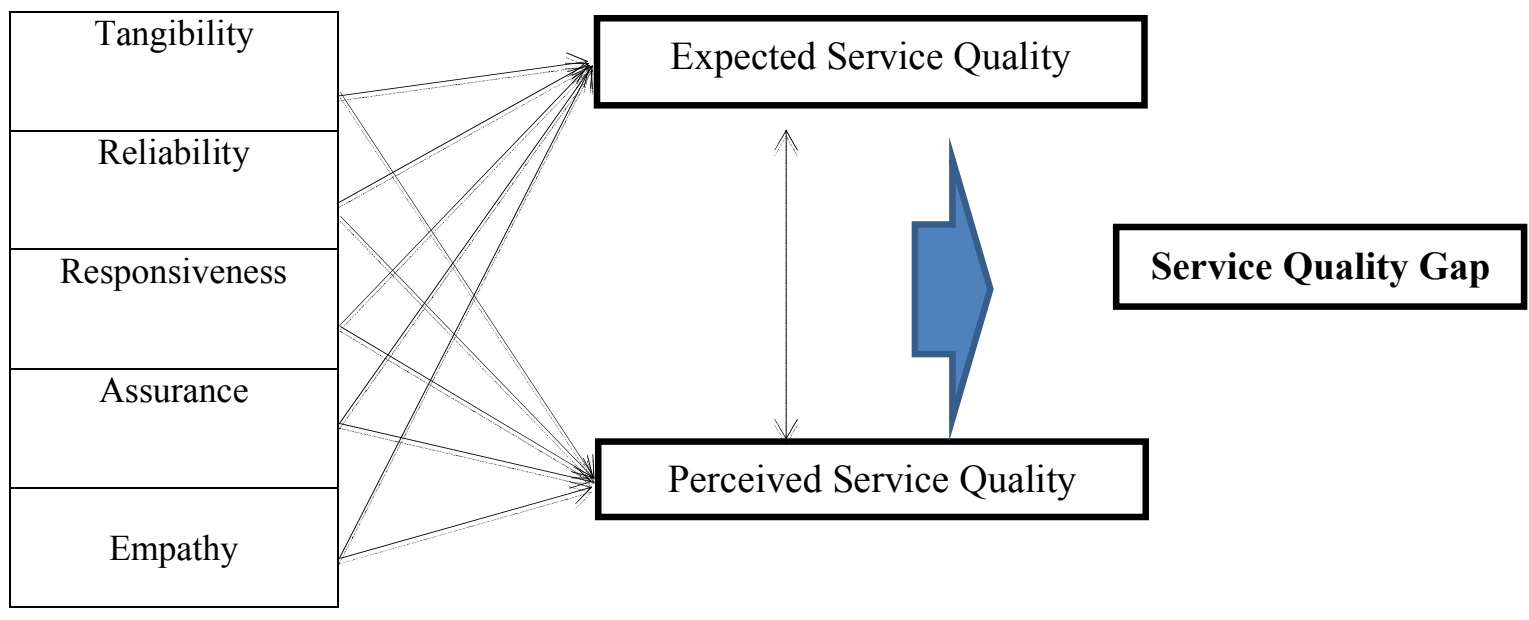

Figurer 1 - Conceptual Framework

Source: Prepared by Authors, 2015

\subsection{Dimensions of Service quality in SERVQUAL Model}

The SERVQUAL instrument has five generic dimensions or constructs which are stated as follows (Rahaman, Abdullah, \& Rahman, 2011).

Tangibles: Physical facilities, appearance of personnel and equipment.

Reliability: Ability to perform the promised service accurately and dependably.

Responsiveness: Provide prompt service and willingness to help customers.

Assurance: (including all these dimensions such as courtesy, competence, security and credibility) Courtesy and Knowledge of employees and their ability to inspire trust and confidence.

Empathy: (including all these dimensions such as access, communication, and understanding the customer) Caring and individualized attention that the firm provides to its customers.

In this study of SERVQUAL analysis, 22 statements used to measure the performance across above mentioned five dimensions, using seven point likert scale measuring both customer expectations and perceptions. 
Proceedings of $12^{\text {th }}$ International Conference on Business Management

http://ssrn.com/link/12th-ICBM-2015.html

$7^{\text {th }}$ and $8^{\text {th }}$ December $2015 \mid$ Colombo, Sri Lanka

Table 1 - Operationalization of Variables Used in the Study

\begin{tabular}{|c|c|c|c|}
\hline Concept & Variable & Indicator & Sources \\
\hline \multirow[t]{5}{*}{$\begin{array}{l}\text { Service Quality } \\
\text { (Comparison } \\
\text { between } \\
\text { Expectation and } \\
\text { Perception) }\end{array}$} & Tangibles & $\begin{array}{l}\text { - Using modern equipment } \\
\text { - Physical facilities are visually } \\
\text { appealing } \\
\text { - Neat appearing } \\
\text { - Materials associated with the } \\
\text { service are visually appealing }\end{array}$ & \multirow{3}{*}{$\begin{array}{l}\text { (Parasuraman et al., } \\
\text { 1988) } \\
\text { (Rahaman et al., 2011) } \\
\text { (Naik, Gantasala, \& } \\
\text { Prabhakar, 2010) }\end{array}$} \\
\hline & Reliability & $\begin{array}{l}\text { - Speed of service sincere } \\
\text { interest in solving problem } \\
\text { - Shows sincere interest in } \\
\text { solving problems } \\
\text { - Perform the service right the } \\
\text { first time } \\
\text { - Provide the service at the right } \\
\text { time } \\
\text { - Error free recording }\end{array}$ & \\
\hline & Responsiveness & $\begin{array}{l}\text { - Tell when exactly service will } \\
\text { be performed } \\
\text { - Information are easily obtained } \\
\text { by customers } \\
\text { - Give prompt service to } \\
\text { customers } \\
\text { - Willing to help customers } \\
\text { - Never be too busy to respond to } \\
\text { customers }\end{array}$ & \\
\hline & Assurance & $\begin{array}{l}\text { - Instill confidence in customers } \\
\text { - Safe transactions } \\
\text { - Consistently courteous with } \\
\text { customers } \\
\text { - Knowledgeable employees }\end{array}$ & \\
\hline & Empathy & $\begin{array}{l}\text { - Give customers individual } \\
\text { attention } \\
\text { - Convenient operating hours } \\
\text { - Give customers personal } \\
\text { attention } \\
\text { - Understand specific needs of } \\
\text { customers }\end{array}$ & \\
\hline
\end{tabular}

Source: Authors, 2015

\subsection{Hypothesis}

Following hypothesis has derived with the above conceptual framework developed with the view of answering to the second objective -- to analyze the satisfaction level of public on service quality of Urban Local Authorities

$\mathrm{H}_{0 \text { : }}$ There is no gap between expected service quality and perceived service quality

$\mathrm{H}_{1:}$ There is a gap between expected service quality and perceived service quality

Gangodawilla, Nugegoda

E-Mail: icbm@sjp.ac.lk

WEB: www.icbmusjp.org, mgt.sjp.ac.lk 
$7^{\text {th }}$ and $8^{\text {th }}$ December $2015 \mid$ Colombo, Sri Lanka

\section{Methodology}

This is a quantitative study and research design is cross-sectional in which data collected from beneficiaries using questionnaires in order to make the study very objective. Study is based on a model which already has been designed and this model called the SERVQUAL model which would enable obtaining answers from beneficiaries about their perceptions and assume the phenomena, customer satisfaction and service quality already exist out there and the beneficiaries are aware of them. Data collected from the respondents will be analyzed using SPSS software.

The data were collected by using a structured questionnaire, which consists of three parts. Part I was designed to gather information about the respondent's demographic background such as gender, educational level, age, marital status, income and occupation. Part II consists of 22 statements related to measure respondents' perception towards the service quality of urban local authorities. The SERVQUAL scale that was designed by Parasuraman et al. (1991) was used in entirety in this study. The respondents were asked to rate their level of agreement with each statement using seven-point scale ranging from 1 (Strongly Disagree) to 7 (Strongly Agree). Higher levels of service quality is indicated from higher scores on this scale. Section III was designed to gather information about respondents' overall satisfaction with services provided by the municipal council. It consists of six statements, adapted from Cronin and Taylor (1992) and were measured with reference to a 7-point rating scale $(1=$ Very Dissatisfied to $7=$ Very Satisfied).

As previously mentioned, this study is mainly focused on analysis of Public Satisfaction on Services Quality of Urban Local Authorities in Sri Lanka. To meet the objectives of the study, the researchers aim to select general public who obtain services from the Urban Local Authorities in Sri Lanka as unit of sampling. Sampling method of the study is judgmental sampling and sample size was 200 individuals from urban local authorities where the sample size can be justified through (Donnelly \& White, 2012).

\section{Data Analysis}

The purpose of this study is to analyze the Public Satisfaction on Services Quality of Urban Local Authorities in Sri Lanka. To explore this broader purpose, data were collected from two hundred (200) respondents from four (04) urban local authorities; Colombo district in Sri 
$7^{\text {th }}$ and $8^{\text {th }}$ December $2015 \mid$ Colombo, Sri Lanka

Lanka. As per that, fifty (50) no of people who obtain services from each authority were interviewed.

Firstly, it describes the profile of the sample and descriptive data. Secondly, the data were cleaned and check for normality. Thirdly data were presented and analyzed to identify the Public Satisfaction on Services Quality of Urban Local Authorities in Sri Lanka with a view to meet the objectives of the study.

Data analysis for this study has been done in two types of steps, the preliminary analysis and the main analysis. For preliminary analysis which involves mainly descriptive statistics to summarize data, the demographic characteristics of the respondents were outlined in order to simplify the understanding of the data. The main analysis involved factor analysis whose purpose to find out if the SERVQUAL is applicable in the context of local authorities and the gap score analysis whereby descriptive statistics were applied to summarize means of perceptions and expectations of beneficiaries. Researchers calculate the perception minus expectation scores for each item and dimension in order to identify the service quality gaps.

Checking the reliability and validity of the modified SERVQUAL model made up of six dimensions, as in the table 7, Cronbach's alpha was computed for each dimension of the SERVQUAL model and factor analysis carried out to test validity. The Cronbach's alpha ranges between 0 (denoting no internal reliability) and 1 (denoting perfect internal reliability). The first part of the data analysis was to check the internal reliability of results in order to determine the credibility of findings results from the study since dealing with multiple-item measure that is the modified SERVQUAL model made up of 6 dimensions measuring service quality. In other words reliability checks whether or not respondents' scores on any one indicator tend to be related to their scores on the other indicators (Bryman \& Bell, 2007). 
Proceedings of $12^{\text {th }}$ International Conference on Business Management

http://ssrn.com/link/12th-ICBM-2015.html

$7^{\text {th }}$ and $8^{\text {th }}$ December $2015 \mid$ Colombo, Sri Lanka

Table 2 - Gender Composition of Each Council in the Selected Sample

\begin{tabular}{|l|r|r|r|}
\hline \multirow{2}{*}{ Name of the LA } & \multicolumn{2}{c|}{ Gender } & \multicolumn{1}{c|}{ Total } \\
\cline { 2 - 4 } & \multicolumn{1}{|c|}{ Male } & \multicolumn{1}{|c|}{ Female } & \\
\hline CMC & $17.0 \%$ & $8.0 \%$ & $25.0 \%$ \\
\hline Maharagama UC & $18.0 \%$ & $7.0 \%$ & $25.0 \%$ \\
\hline Boralesgamuwa UC & $12.0 \%$ & $13.0 \%$ & $25.0 \%$ \\
\hline Dehiwala Mt Levenia MC & $8.5 \%$ & $16.5 \%$ & $25.0 \%$ \\
\hline Total & $55.5 \%$ & $44.5 \%$ & $100.0 \%$ \\
\hline
\end{tabular}

Source: Authors, 2015

The demographic profile of the respondents is described as in the table 2; males were $55.5 \%$ while females were $44.5 \%$ slightly lower than males. Table 3 shows that a majority of the respondents were 40-59 age groups.

Table 3 - Age Groups Comparison in the Selected Sample

\begin{tabular}{|c|c|c|c|c|c|}
\hline \multirow{2}{*}{ Name of the LA } & \multicolumn{4}{|c|}{ Age Group } & \multirow[t]{2}{*}{ Total } \\
\hline & $<25$ & $25-39$ & 40-59 & $>60$ & \\
\hline $\mathrm{CMC}$ & $0.5 \%$ & $11.5 \%$ & $12.0 \%$ & $1.0 \%$ & $25.0 \%$ \\
\hline Maharagama UC & & $5.5 \%$ & $13.5 \%$ & $6.0 \%$ & $25.0 \%$ \\
\hline Boralesgamuwa UC & $0.5 \%$ & $10.5 \%$ & $13.0 \%$ & $1.0 \%$ & $25.0 \%$ \\
\hline Dehiwala Mt Levenia MC & $4.5 \%$ & $10.0 \%$ & $9.0 \%$ & $1.5 \%$ & $25.0 \%$ \\
\hline Total & $5.5 \%$ & $37.5 \%$ & $47.5 \%$ & $9.5 \%$ & $100.0 \%$ \\
\hline
\end{tabular}

Source: Authors, 2015

Table 4 - Education Level Comparison in the Selected Sample

\begin{tabular}{|c|c|c|c|c|c|c|c|c|c|c|}
\hline \multirow{2}{*}{$\begin{array}{l}\text { Name of the } \\
\text { LA }\end{array}$} & \multicolumn{9}{|c|}{ Education Level } & \multirow[t]{2}{*}{ Total } \\
\hline & \begin{tabular}{|c} 
No \\
schooling( \\
Can read \\
and write)
\end{tabular} & $<\mathbf{O} / \mathrm{L}$ & $\begin{array}{c}\text { Passed } \\
\text { O/L }\end{array}$ & $\begin{array}{c}\text { Passed } \\
\mathbf{A} / \mathbf{L}\end{array}$ & $\begin{array}{l}\text { Diploma } \\
\text { Holder }\end{array}$ & $\begin{array}{l}\text { Degree } \\
\text { Holder }\end{array}$ & $\begin{array}{c}\text { PGD } \\
\text { Holder }\end{array}$ & $\begin{array}{c}\text { Professiona } \\
\text { l } \\
\text { Qualificati } \\
\text { ons }\end{array}$ & NR & \\
\hline $\mathrm{CMC}$ & & $0.5 \%$ & $9.0 \%$ & $12.5 \%$ & $1.0 \%$ & $1.5 \%$ & & $0.5 \%$ & & $25.0 \%$ \\
\hline $\begin{array}{l}\text { Maharagama } \\
\text { UC }\end{array}$ & & $0.5 \%$ & $5.5 \%$ & $10.5 \%$ & $1.5 \%$ & $4.0 \%$ & & $3.0 \%$ & & $25.0 \%$ \\
\hline $\begin{array}{l}\text { Boralesgamuw } \\
\text { a UC }\end{array}$ & & $0.5 \%$ & $2.0 \%$ & $10.5 \%$ & $3.5 \%$ & $5.5 \%$ & $1.0 \%$ & $1.0 \%$ & $1.0 \%$ & $25.0 \%$ \\
\hline $\begin{array}{l}\text { Dehiwala Mt } \\
\text { Levenia MC }\end{array}$ & $1.0 \%$ & $2.5 \%$ & $6.0 \%$ & $7.5 \%$ & & $8.0 \%$ & & & & $25.0 \%$ \\
\hline Total & $1.0 \%$ & $4.0 \%$ & $22.5 \%$ & $41.0 \%$ & $6.0 \%$ & $19.0 \%$ & $1.0 \%$ & $4.5 \%$ & $1.0 \%$ & $100.0 \%$ \\
\hline
\end{tabular}

Source: Authors, 2015

A majority of the respondents were qualified with Passed G.C.E A/L forming 41.0\%, followed by G.C.E A/L, 22.5\% and Degree Holders formed 19.0\%.

Gangodawilla, Nugegoda

E-Mail: icbm@sjp.ac.lk

WEB: www.icbmusjp.org, mgt.sjp.ac.lk 
Proceedings of $12^{\text {th }}$ International Conference on Business Management

http://ssrn.com/link/12th-ICBM-2015.html

$7^{\text {th }}$ and $8^{\text {th }}$ December $2015 \mid$ Colombo, Sri Lanka

Table 5 - Occupation the Respondents in Each Council

\begin{tabular}{|c|c|c|c|c|c|c|c|c|c|}
\hline \multirow[t]{2}{*}{ Name of the LA } & \multicolumn{8}{|c|}{ Occupation } & \multirow[t]{2}{*}{ Total } \\
\hline & $\begin{array}{c}\text { Gov / } \\
\text { Pvt } \\
\text { Admin }\end{array}$ & \begin{tabular}{|c|} 
Gov / \\
Pvt \\
Clerical
\end{tabular} & \begin{tabular}{|c|} 
Gov / \\
Pvt \\
Minor \\
Service \\
\end{tabular} & \begin{tabular}{|c|}
$\begin{array}{c}\text { Self- } \\
\text { Employed } \\
\text { (Large } \\
\text { Scale) }\end{array}$ \\
\end{tabular} & \begin{tabular}{|c|} 
Self- \\
Employed \\
(Small \\
Scale) \\
\end{tabular} & Retired & $\begin{array}{c}\text { Not } \\
\text { Employed }\end{array}$ & Other & \\
\hline $\mathrm{CMC}$ & $2.0 \%$ & $9.5 \%$ & $1.5 \%$ & $2.5 \%$ & $3.5 \%$ & $1.5 \%$ & $4.0 \%$ & $0.5 \%$ & $25.0 \%$ \\
\hline Maharagama UC & $5.5 \%$ & $7.5 \%$ & $6.0 \%$ & - & $1.0 \%$ & $2.0 \%$ & $3.0 \%$ & & $25.0 \%$ \\
\hline $\begin{array}{l}\text { Boralesgamuwa } \\
\text { UC }\end{array}$ & $3.0 \%$ & $12.5 \%$ & $4.0 \%$ & - & $0.5 \%$ & $4.5 \%$ & $0.5 \%$ & & $25.0 \%$ \\
\hline $\begin{array}{l}\text { Dehiwala Mt } \\
\text { Levenia MC }\end{array}$ & $4.0 \%$ & $1.0 \%$ & $2.0 \%$ & - & $2.0 \%$ & $4.5 \%$ & $10.0 \%$ & $1.5 \%$ & $25.0 \%$ \\
\hline Total & $14.5 \%$ & $30.5 \%$ & $13.5 \%$ & $2.5 \%$ & $7.0 \%$ & $12.5 \%$ & $17.5 \%$ & $2.0 \%$ & $100.0 \%$ \\
\hline
\end{tabular}

Source: Authors, 2015

As per the table 5, majority of the respondents are in public or private sector clerical services; $30.5 \%$ out of that $12.5 \%$ recorded in the Boralesgamuwa Urban Council and public or private sector administration position holders are $14.5 \%$ of the total sample where majority is 5.5\% from Maharagama Urban Council .

Table 6 - Income Level of the Respondents

\begin{tabular}{|c|c|c|c|c|c|c|c|c|c|}
\hline \multirow[t]{2}{*}{ Name of the LA } & \multicolumn{8}{|c|}{ Income } & \multirow[t]{2}{*}{ Total } \\
\hline & $<15000$ & $\begin{array}{l}15000- \\
30000\end{array}$ & $\begin{array}{l}31000- \\
45000 \\
\end{array}$ & $\begin{array}{c}46000- \\
60000 \\
\end{array}$ & $\begin{array}{l}61000- \\
75000 \\
\end{array}$ & $\begin{array}{l}76000- \\
90000 \\
\end{array}$ & $\begin{array}{l}91000- \\
105000 \\
\end{array}$ & $>105000$ & \\
\hline CMC & & $14.0 \%$ & $7.0 \%$ & $2.0 \%$ & $0.5 \%$ & $1.0 \%$ & & $0.5 \%$ & $25.0 \%$ \\
\hline Maharagama UC & $0.5 \%$ & $15.0 \%$ & $7.5 \%$ & $2.0 \%$ & & & & & $25.0 \%$ \\
\hline $\begin{array}{l}\text { Boralesgamuwa } \\
\text { UC }\end{array}$ & & $8.5 \%$ & $10.5 \%$ & $3.5 \%$ & $1.0 \%$ & $1.0 \%$ & & $0.5 \%$ & $25.0 \%$ \\
\hline \begin{tabular}{|l} 
Dehiwala Mt \\
Levenia MC
\end{tabular} & $7.5 \%$ & $8.5 \%$ & $2.5 \%$ & $4.0 \%$ & & $1.5 \%$ & $1.0 \%$ & & $25.0 \%$ \\
\hline Total & $8.0 \%$ & $46.0 \%$ & $27.5 \%$ & $11.5 \%$ & $1.5 \%$ & $3.5 \%$ & $1.0 \%$ & $1.0 \%$ & $100.0 \%$ \\
\hline
\end{tabular}

Source: Authors, 2015

As per as income levels are concerned, $46.0 \%$ of the total earns Rs. 15,000 to Rs. 30,000 per month.

Table 7 - Reliability Coefficient (Cronbach's alphas)

\begin{tabular}{|l|l|l|l|}
\hline Dimension & Sub-Dimension & No of items & Cronbach's Alpha \\
\hline \multirow{2}{*}{ Tangibility } & Expected & 4 & 0.673 \\
\cline { 2 - 4 } & Perceived & 4 & 0.680 \\
\hline \multirow{2}{*}{ Responsiveness } & Expected & 4 & 0.815 \\
\cline { 2 - 4 } & Perceived & 4 & 0.780 \\
\hline \multirow{2}{*}{ Eeliability } & Expected & 4 & 0.606 \\
\cline { 2 - 4 } & Perceived & 4 & 0.690 \\
\hline \multirow{2}{*}{ Assurance } & Expected & 4 & 0.932 \\
\cline { 2 - 4 } & Perceived & 4 & 0.890 \\
\cline { 2 - 4 } & Expected & 4 & 0.780 \\
\cline { 2 - 4 } & Perceived & 4 & 0.695 \\
\hline
\end{tabular}

Source: Authors, 2015 
$7^{\text {th }}$ and $8^{\text {th }}$ December $2015 \mid$ Colombo, Sri Lanka

As in the table 7, the internal consistency of the modified SERVQUAL items was assessed by computing the total reliability scale. The reliability scales for the study vary from 0.67 to 0.932, indicating an overall reliability factor slightly same to that of (Parasuraman et al., 1988) study which was 0.92 . This reliability value for this study is substantial considering the fact that the highest reliability that can be obtained is 1.0 and this is an indication that the items of the four dimensions of SERVQUAL model are accepted for analysis.

Looking at the reliability coefficients of all five dimensions on table 7, some dimensions have coefficients slightly below 0.7 , Tangibility (0.673) and Reliability (0.606). This could as a result that some items under each dimension seemed too similar. The dimension, products had a very low reliability coefficient, 0.434 and this could have been because of the small number of items (4) used in that dimension. Other dimensions, Assurance, Responsiveness and Empathy show coefficients higher than 0.7, meaning these dimensions comprising of various items show a true measure of service quality.

\subsection{Expectations and Perceptions of Services Provided by Local Authorities}

Expectations and perceptions were both measured using the 7-point likert scale whereby the higher numbers indicate higher level of expectation or perception. In general speaking, people's expectation exceeded the perceived level of service shown by the perception scores. This resulted in a negative gap score (Perception - Expectation). According to (Parasuraman et al., 1988) it is however common for consumer's expectation to exceed the actual service perceived and this signifies that there is always need for improvement.

As in the table 8, the gap scores are the difference between the perception and expectation scores with a range of values from -6 to +6 and these gap scores measure service quality and hence public satisfaction. The more perceptions are close to expectations, the higher the perceived level of quality.

The items with the highest expectation scores were clean responsiveness (15.78). However, this score is very different from scores of other items and this implies generally, people expect very high level of responsiveness to their requirements from Local Authorities.

The items rated highest for actual service perceived were, in Boralesgamuwa UC where 69.34 gap is observable, Dehiwala Mt Lavenia MC (3.80), CMC (-2.48) and Maharagama 
UC is -0.36 . According to that gap scores, people expect service from Boralesgamuwa UC and Dehiwala Mt Lavenia MC are more frustrated.

Table 8 - Service Quality Gap Analysis

\begin{tabular}{|c|c|c|c|c|c|c|c|c|c|c|c|c|}
\hline \multirow{2}{*}{ Dimension } & \multicolumn{3}{|c|}{ CMC } & \multicolumn{3}{|c|}{ Maharagama UC } & \multicolumn{3}{|c|}{ Boralesgamuwa UC } & \multicolumn{3}{|c|}{ Dehiwala Mt Lavenia MC } \\
\hline & EX & PER & Gap & EX & PER & Gap & EX & PER & Gap & EX & PER & Gap \\
\hline \multirow{4}{*}{ Tangible } & 6.26 & 6.42 & -0.16 & 6.14 & 6.14 & 0.00 & 6.46 & 3.68 & 2.78 & 5.14 & 4.44 & 0.7 \\
\hline & 6.22 & 6.20 & 0.02 & 6.28 & 6.36 & -0.08 & 6.54 & 3.86 & 2.68 & 5.00 & 4.44 & 0.6 \\
\hline & 6.24 & 6.36 & -0.12 & 6.46 & 6.40 & 0.06 & 6.60 & 3.72 & 2.88 & 5.14 & 4.58 & 0.6 \\
\hline & 6.20 & 6.32 & -0.12 & 6.22 & 6.28 & -0.06 & 6.42 & 3.68 & 2.74 & 5.32 & 4.32 & 1.0 \\
\hline & & & -0.38 & & & -0.08 & & & 11.08 & & & 2.9 \\
\hline \multirow{6}{*}{ Reliability } & 6.12 & 6.34 & -0.22 & 5.92 & 6.02 & -0.10 & 6.64 & 3.60 & 3.04 & 5.06 & 4.62 & 0.4 \\
\hline & 6.22 & 6.24 & -0.02 & 6.04 & 6.10 & -0.06 & 6.50 & 3.58 & 2.92 & 5.14 & 5.00 & 0.1 \\
\hline & 6.02 & 6.20 & -0.18 & 5.90 & 5.94 & $\begin{array}{l}-0.04 \\
\end{array}$ & 6.60 & 3.38 & 3.22 & 5.44 & 4.94 & 0.5 \\
\hline & 6.12 & 6.16 & -0.04 & 6.04 & 6.00 & 0.04 & 6.52 & 3.72 & 2.80 & 5.12 & 4.88 & 0.2 \\
\hline & 6.08 & 6.26 & -0.18 & 6.10 & 6.10 & 0.00 & 6.68 & 3.62 & 3.06 & 5.24 & 4.42 & 0.8 \\
\hline & & & -0.64 & & & -0.16 & & & 15.04 & & & 2.14 \\
\hline \multirow{6}{*}{$\begin{array}{c}\text { Responsivenes } \\
\mathrm{s}\end{array}$} & 6.10 & 6.28 & -0.18 & 5.90 & 5.90 & 0.00 & 6.58 & 3.14 & 3.44 & 5.14 & 5.18 & 0.0 \\
\hline & 6.22 & 6.24 & -0.02 & 5.90 & 5.88 & 0.02 & 6.70 & 3.38 & 3.32 & 5.20 & 5.16 & 0.0 \\
\hline & 6.08 & 6.26 & -0.18 & 6.12 & 6.12 & 0.00 & 6.56 & 3.32 & 3.24 & 5.12 & 5.06 & 0.1 \\
\hline & 6.26 & 6.28 & -0.02 & 6.16 & 6.16 & 0.00 & 6.64 & 3.62 & 3.02 & 5.18 & 5.42 & -0.2 \\
\hline & 6.18 & 6.50 & $-\mathbf{0 . 3 2}$ & 6.14 & 6.14 & 0.00 & 6.62 & 3.86 & 2.76 & 5.24 & 5.02 & 0.2 \\
\hline & & & -0.72 & & & 0.02 & & & 15.78 & & & 0.04 \\
\hline \multirow{5}{*}{ Assurance } & 6.20 & 6.26 & -0.06 & 6.36 & 6.36 & 0.00 & 6.52 & 3.48 & 3.04 & 5.12 & 5.30 & -0.2 \\
\hline & 6.14 & 6.40 & -0.26 & 6.56 & 6.64 & -0.08 & 6.72 & 3.68 & 3.04 & 5.58 & 5.20 & 0.4 \\
\hline & 6.18 & 6.20 & -0.02 & 6.06 & 6.18 & -0.12 & 6.56 & 3.64 & 2.92 & 5.50 & 5.22 & 0.3 \\
\hline & 6.16 & 6.40 & -0.24 & 6.24 & 6.26 & -0.02 & 6.64 & 3.62 & 3.02 & 5.54 & 5.60 & -0.1 \\
\hline & & & -0.58 & & & -0.22 & & & 12.02 & & & 0.42 \\
\hline \multirow{7}{*}{ Empathy } & 6.24 & 6.26 & -0.02 & 6.40 & 6.38 & 0.02 & 6.56 & 3.44 & 3.12 & 5.36 & 5.46 & -0.1 \\
\hline & 6.20 & 6.24 & -0.04 & 6.36 & 6.30 & 0.06 & 6.64 & 3.48 & 3.16 & 5.16 & 5.48 & -0.3 \\
\hline & 6.24 & 6.26 & -0.02 & 6.32 & 6.30 & 0.02 & 6.60 & 3.56 & 3.04 & 5.08 & 5.52 & -0.4 \\
\hline & 6.24 & 6.24 & 0.00 & 6.38 & 6.42 & -0.04 & 6.54 & 3.54 & 3.00 & 5.14 & 5.40 & -0.3 \\
\hline & 6.20 & 6.28 & -0.08 & 6.40 & 6.38 & 0.02 & 6.66 & 3.56 & 3.10 & 5.20 & 5.70 & -0.5 \\
\hline & & & -0.16 & & & 0.08 & & & 15.42 & & & -1.62 \\
\hline & & & -2.48 & & & -0.36 & & & 69.34 & & & 3.80 \\
\hline
\end{tabular}

Source: Authors, 2015 


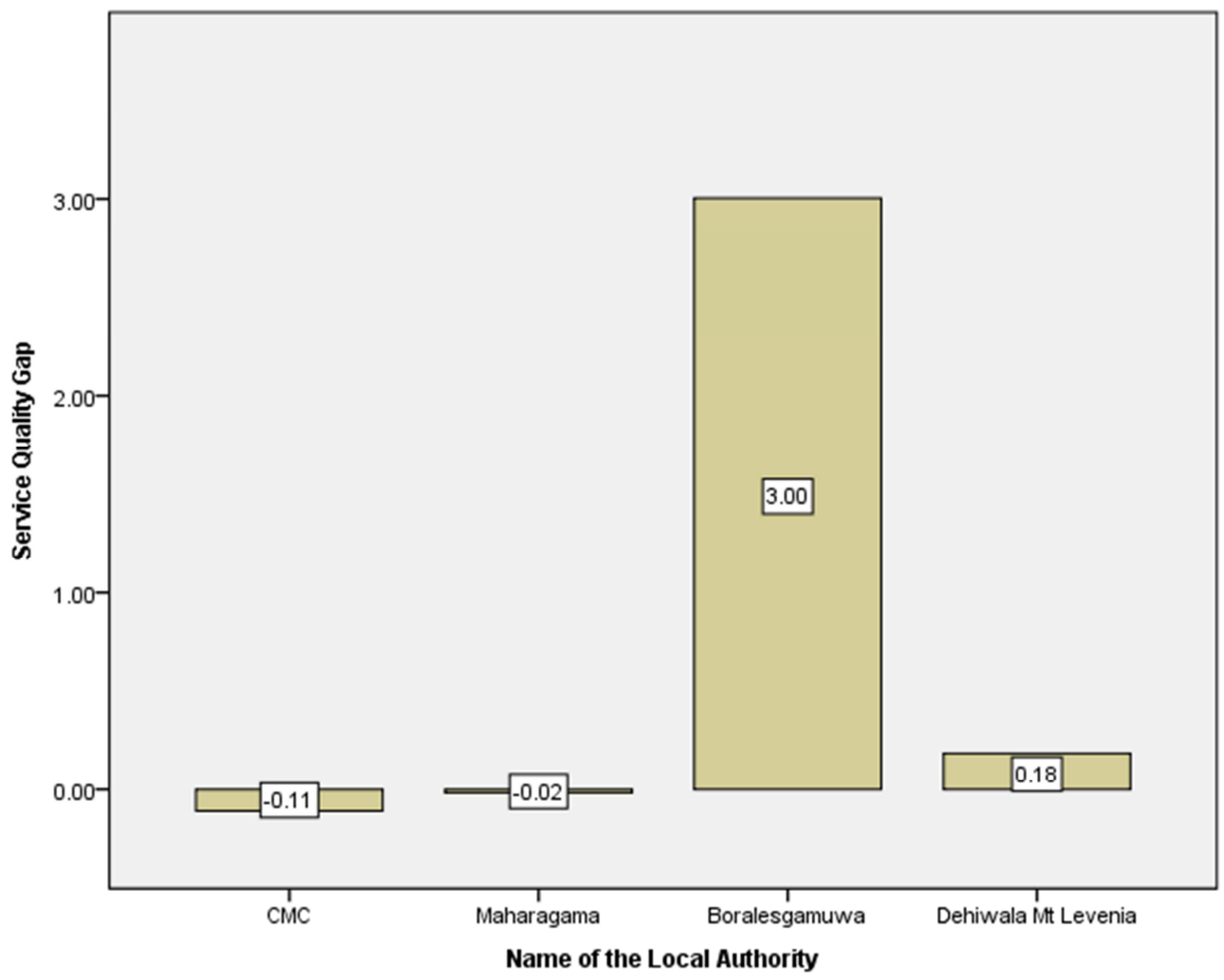

Figure 2 - Overall Service Quality Gaps in Selected Local Authorities

Finally, considering all aspects by which public are satisfied related to the services provided by the local authorities in selected sample, Maharagama UC is providing expected services as it is; with a small gap -0.02. Also CMC's gap - 0.11 indicates a better sign of their services without having a large gap. However, Boralesgamuwa UC is the most inefficient services providing local authority which scores a 3.00 gap. As per the gap shows in the table 8, Dehiwal Mt. Levenia is also slightly weak service providing local authority

\section{Conclusions}

From the analysis carried out in order to answer the aforesaid research questions and hence fulfill the purpose of the study which include; theoretically trying to find out if the SERVQUAL model is used to measure of service quality in urban local authorities in Sri Lanka selecting four local authorities and empirically finding out how people perceive service quality in local authorities by identifying what dimensions bring satisfaction.

The lack of fit of data collected using the modified SERVQUAL model which is shown in the factor analysis was realized. Also, the SERVQUAL model provided a satisfactory level of 
overall reliability (0.92) which is almost same to (Parasuraman et al., 1988) study on SERVQUAL but some dimensions (tangibles, responsiveness ) did not show enough reliability in this study meaning some items were not cohesive in forming some dimensions. Finally, the items with the highest expectation gap scores were responsiveness (15.78). However, this score is very different from scores of other items and this implies generally, people expect very high level of responsiveness to their requirements from Local Authorities.

The items rated highest for actual service perceived were, in Boralesgamuwa UC where 69.34 gap was observed, Dehiwala Mt Lavenia MC (3.80), CMC (-2.48) and Maharagama $\mathrm{UC}$ is -0.36 . According to that gap scores, people expect service from Boralesgamuwa UC and Dehiwala Mt Lavenia MC are more frustrated.

There are several limitations in this study such as the study is limited to the Urban Local Authorities; in Colombo-Sri Lanka, this study is based on gap 5 in the SERVQUAL-model that is about the difference between expected and perceived quality of service, and the model of SERVQUAL is consisted of totally 5 different gaps that can occur within the service business, the population sample is not focused on any specific target group and therefore it is not possible to make any kind of generalizations about different groups.

However, further research on this area is required to verify the findings and find out the reasons/causes to the dissatisfaction (gap) of the people who look for services from Local Authorities in Sri Lanka.

\section{References}

Benlian, A., Koufaris, M., \& Hess, T. (2012). Service Quality in Software-as-a-Service: Developing the SaaS-

Qual Measure and Examining Its Role in Usage Continuance. Journal of Management Information Systems, 28(3), 85-126. http://doi.org/10.2753/MIS0742-1222280303

Daniel, C. N., \& Berinyuy, L. P. (2010). Using the SERVQUAL Model to assess Service Quality and Customer. Donnelly, P. M., \& White, E. P. (2012). Assessing the Quality of a Local Authority Conference and Hospitality

Venue using the ServQual Model, 1-3.

Johnston, R. (1995). the Determinants of Service Quality - Satisfiers and Dissatisfiers, 6(5), 53-71.

http://doi.org/10.1108/09564239510101536

Kabir, M. H., \& Carlsson, T. (2010). Service Quality, 1-51.

Mokhlis, S., Aleesa, Y., \& Mamat, I. (2011). Municipal Service Quality and Citizen Satisfaction in Southern

Thailand. Journal of Public Administration and Governance, 1(1), 122-137.

http://doi.org/10.5296/jpag.v1i1.717

Faculty of Management Studies and Commerce

University of Sri Jayewardenepura

Gangodawilla, Nugegoda

E-Mail:icbm@sjp.ac.lk

WEB: www.icbmusjp.org, mgt.sjp.ac.lk 
Proceedings of $12^{\text {th }}$ International Conference on Business Management http://ssrn.com/link/12th-ICBM-2015.html

$7^{\text {th }}$ and $8^{\text {th }}$ December $2015 \mid$ Colombo, Sri Lanka

Naik, C. N. K., Gantasala, S. B., \& Prabhakar, G. V. (2010). Service Quality (Servqual) and its Effect on

Customer Satisfaction in Retailing. European Journal of Social Sciences, 16(2), 231-243. Retrieved from

http://lms.ctu.edu.vn/dokeos/courses/KT321/document/LUOC_KHAO_TAI_LIEU/chat_luong_dich_vu_va_

su_hai_long_cua_dv_ban_le.pdf

Parasuraman, a, Zeithaml, V. a, \& Berry, L. L. (1985). A conceptual model of service quality and its implications for future research. The Journal of Marketing, 49(4), 41-50. http://doi.org/10.2307/1251430

Parasuraman, a, Zeithaml, V. a, \& Berry, L. L. (1988). SERQUAL: A Multiple-Item scale for Measuring

Consumer Perceptions of Service Quality. Journal of Retailing. http://doi.org/10.1016/S0148-

2963(99)00084-3

Rahaman, M. M., Abdullah, M., \& Rahman, A. (2011). Measuring Service Quality using SERVQUAL Model : A Study on PCBs ( Private Commercial Banks ) in Bangladesh @ Society for Business and Management Dynamics $\odot$ Society for Business and Management Dynamics. Business Management Dynamics, 1(1), 111. 